\title{
Enzymatic Profile Aactivity of Grass Carp (Ctenopharyngodon Idella) After Exposure to the Pollutant Named Atrazine (Herbicide)
}

\author{
Ahsan Khan'*, Ali Muhammad Yousafzai², Nazish Shah', Muhammad', \\ Munawar Saleem Ahmad', Muhammad Farooq ${ }^{3}$, Fawad Aziz', Muhammad Adnan ${ }^{4}$, \\ Muhammad Rizwan ${ }^{5}$, Shahibzada Muhammad Jawad ${ }^{2}$ \\ ${ }^{1}$ Department of Zoology, University of Swabi, Khyber Pakhtunkhwa, Pakistan \\ ${ }^{2}$ Department of Zoology, Islamia College Peshawar, Khyber Pakhtunkhwa, Pakistan \\ ${ }^{3}$ Department of Microbiology, University of Swabi, Khyber Pakhtunkhwa, Pakistan \\ ${ }^{4}$ Department of Agriculture, University of Swabi, Khyber Pakhtunkhwa, Pakistan \\ ${ }^{5}$ Center of Biotechnology and Microbiology, University of Peshawar, Khyber Pakhtunkhwa, Pakistan
}

Received: 30 March 2016

Accepted: 24 April 2016

\begin{abstract}
The present study contemplates the enzymatic profile of grass carp, including lactate dehydrogenase (LDH), creatinine phosphokinases (CPK), serum glutamic-pyruvic transaminase (SGPT), and alkaline phosphatase (Alk Phosp) under atrazine's acute toxicity effects $\left(\mathrm{LC}_{50}\right)$ for $01(15 \mu \mathrm{l} / \mathrm{L}), 02(13 \mu \mathrm{l} / \mathrm{L}), 03$ $(10 \mu \mathrm{l} / \mathrm{L})$, and $04(08 \mu \mathrm{l} / \mathrm{L})$ days/concentration, respectively. For analyzing the enzymatic profile we followed the biochemical analyzer set protocol (Merck micro lab 300 biochemistry analyzer) in the laboratory. Control group concentrations for LDH, CPK, SGPT, and Alk Phosp were $342 \mathrm{IU} / \mathrm{ml}, 7513.3 \mathrm{IU} / \mathrm{ml}$, $46 \mathrm{mmol} / \mathrm{l}$, and $126.6 \mathrm{IU} / \mathrm{ml}$, respectively. After treatment LDH concentrations were $906,851,765$, and 545 $\mathrm{IU} / \mathrm{ml}$, respectively. CPK concentrations were 1,737, 2,445, 3,718, and 5,767 IU/ml, respectively. SGPT concentrations were 27, 24.3, 13.67, and 8.67, respectively, and Alk Phosp concentrations were 50.3, 30, 22.3, and $17.6 \mathrm{IU} / \mathrm{ml}$, respectively. Maximum inclined $(\mathrm{P} \leq 0.001)$ in concentration of $\mathrm{LDH}$ was observed after $24 \mathrm{hrs}$ exposure because of hepatic tissue damage, resulting in increased membrane permeability causing enhanced leaching out of LDH and as LDH participates in an anaerobic pathway, so increase LDH mean increases of anaerobic metabolism resulting from depletion of energy under environmental stress conditions by atrazine, while other enzymatic components like CPK, SGPT, and Alk Phosp showed kindred attributes in their result, like all parameter concentrations showed perpetual decline $(\mathrm{P} \leq 0.001)$ in their concentrations indicating reduced enzymatic activity due to a reduction in permeability for these enzymes, forcing the enzymes to accumulate in the cells as well as decrease in enzyme synthesis due to intoxication of atrazine.
\end{abstract}

Keywords: grass carp, LDH, CPK, SGPT, Alk Phosp

*e-mail: Ahsanyousafzai27@yahoo.com 


\section{Introduction}

Herbicides are one of the most potentially harmful chemicals introduced into the environment for the purpose of controlling weeds, but unfortunately these chemicals adversely affect non-target organisms, and the majority of them end up in environmental pollution - especially in aquatic bodies - leading to negative impacts on aquatic biota, especially fish [1-3].

LDH is of great importance because it is found both in prokaryote and eukaryote and in high concentrations during tissue damage because concentrations of such enzyme can be used as an indicator of tissue damage. LDH is responsible for converting pyruvate to lactic acid and lactic acid back to pyruvate as conversion of NADH to $\mathrm{NAD}+$ and NAD+ back to NADH [4-5]. CPK, also known as creatine kinase (CK), is an enzyme used to catalyze the reaction of conversion of creatinine to phosphocreatine in the presence of energy. This reaction is reversible and thus by adding one phosphate group, ADP can also be converted to ATP [4]. SGPT is responsible for synthesis and deamination of amino acids during stressful conditions in order to cope with high energy demands. In addition, it can also be used to evaluate environmental stress because environmental stress caused by toxicants or drugs can damage the liver, causing this enzyme to be affected. So we can say that the concentration of this enzyme can be used to detect liver health and normal functioning [6-7]. Dephosphorylation is a process of removing the phosphate group from any molecule such as nucleotide, proteins, etc., and this dephosphorylation is done in the presence of alkaline phosphatase enzyme. This enzyme also plays an important role in mineralizing the skeletal system of animals, thus concluded that alkaline phosphatase plays a role in the growth and development of bones and teeth [8].

Atrazine (2-chloro-4-thylamino-6-isopropylaminostriazine; ATZ) is one of the most commonly used herbicides, and due to its relative persistence in soil because of its high half-life and high solubility in water, environmental contamination by this pollutant has increased in recent years and it is considered moderately toxic, that's why utilization of this herbicide is controversial worldwide, as it is currently banned in Europe [9-10].

ATZ is an effective herbicide because it causes obstruction in the growthlines of unwanted plants by blocking electron transport in photosystem II, thus destroying chlorophyll and hampering the photosynthetic process [11]. When ATZ was first released for agricultural use it was thought that since photosynthesis is limited to plants it would only harm plants and be harmless to animals, but it can also affect animals by different means [12]. Different studies have been conducted on atrazine's effect on fish, including hematological parameters, locomotor activity, immune response, metabolism, oxidative stress, osmoregulatory disturbance, and reproduction, which indicates that fish can serve as bioindicators of environmental pollution and therefore can be used to assess the quality of an aquatic environment because they are directly exposed to chemicals resulting from agricultural production via surface runoff or indirectly through the food chain of an ecosystem [1117]. So in accordance with these previous studies, the present study was designed to investigate the toxic effects of atrazine on grass carp (Ctenopharyngodon idella) following acute toxicity exposure (for 01, 02, 03, and 04 days) by evaluating the enzymatic profile, including LDH, CPK, SGPT, and Alk Phosp.

\section{Material and Methods}

\section{Experimental Fish and Design}

Healthy and active specimens of grass carp (Ctenopharyngodon idella) were selected as a model for the present study and were procured from Sherabad Hatchery, Peshawar, Khyber Pakhtunkhwa, Pakistan. One group, considered the control, consisted of five fish and was kept without treatment. For acute toxicity analysis, 26 fish were taken and made up four groups. Groups 1 and 2 consisted of five fish each, which was treated under a dose of $15 \mu \mathrm{l} / \mathrm{L}$ and $13 \mu \mathrm{l} / \mathrm{L}$ for 24 and $48 \mathrm{hrs}$, respectively. Groups 3 and 4 consisted of eight fish each, which was processed under a dose of $10 \mu \mathrm{l} / \mathrm{L}$ and $08 \mu \mathrm{l} / \mathrm{L}$ for 72 and $96 \mathrm{hrs}$, respectively.

\section{Maintenance of Experimental Fish}

After procurement, all fish were carefully analyzed and treated with $0.2 \% \mathrm{KMno} 4$ solution for 2 minutes before being transferred to acclimatization water tanks for two weeks to get rid of any dermal infections. After acclimatization fish were transferred to experimental tanks containing tapwater for experimentation. Fish were fed properly with commercial food on every alternate day in both acclimatization and experimental tanks. $\mathrm{pH}$ and temperature of the water in both tanks were kept constant and checked every alternate day. Other parameters were additionally checked in both acclimatization and experimental tanks, including total hardness $95 \mathrm{mg} / \mathrm{l}$, calcium hardness $61.6 \mathrm{mg} / \mathrm{l}$, magnesium hardness $35 \mathrm{mg} / \mathrm{l}$, water conductivity $431 \mu \mathrm{S} / \mathrm{cm}$, dissolved oxygen $7.37 \mathrm{ppm}$, total solids $321 \mathrm{mg} / \mathrm{l}$, total dissolved solids $221 \mathrm{mg} / \mathrm{l}$, total suspended solids $100 \mathrm{mg} / \mathrm{l}$, total alkalinity $163.3 \mathrm{mg} / \mathrm{l}$, and chloride $20.3 \mathrm{mg} / \mathrm{l}$. All of these concentrations were in the normal range.

\section{Blood Collection and Preservation}

Blood samples were collected from the freshly anesthetized fish on the spot (using MS 222). Blood samples were collected from the caudal vein of fish and sometimes from direct puncturing of the heart of fish. Blood samples were collected with the help of hypodermic syringes, which were heparinized with the help of a few drops of heparin to avoid blood clotting [18-19]. After collection, blood samples were stored in EDTA tubes and a gel tube for preventing blood clotting, and such tubes 
were then centrifuged at 3,000 RPM to obtain serum for analysis of enzymatic profiles, including: LDH, CPK, SGPT, and Alk Phosp.

\section{Enzymatic Profile Estimation Methods}

We used a Merck 300 biochemical analyzer to analyze the enzymatic profile, and the entire enzymatic profile component was analyzed by proposed protocol of the above-mentioned biochemical analyzer.

\section{Statistical Analysis}

Results were reported in mean, standard deviation, and standard error of mean. SPSS software was used to calculate paired t-test to detect the significant ( $\mathrm{P}$ value) difference between control and experimental means as shown in Tables 1 and 2.

\section{Results and Discussion}

Changes in the biochemical parameters by environmental stressors indicate alterations in metabolism and biochemical processes of the organisms, and measurement of these parameters can be used as the diagnostic tools in fish toxicology to measure the fish health status and to identify the extent of damage to target organs exposed to herbicides [20]. Comparison between the mean of the control group concentration and the treated

Table 1. Control group concentrations.

\begin{tabular}{|c|c|c|c|c|c|c|}
\hline No. & Enzymatic profile & Fish 1 & Fish 2 & Fish 3 & Mean \pm S.D & $\begin{array}{c}\text { Standard error } \\
\text { of mean }\end{array}$ \\
\hline 1 & $\begin{array}{c}\text { LDH } \\
(\mathrm{IU} / \mathrm{ml})\end{array}$ & 342 & 340 & 344 & $342 \pm 2.0$ & 1.15 \\
\hline 2 & $\begin{array}{c}\text { CPK } \\
(\mathrm{IU} / \mathrm{ml})\end{array}$ & 7,510 & 7,500 & 7,530 & $7,513.3 \pm 15.2$ & 8.8 \\
\hline 3 & $\begin{array}{c}\text { SGPT } \\
(\mathrm{mmol} / \mathrm{L})\end{array}$ & 42 & 44 & 52 & $46 \pm 5.2$ & 3.0 \\
\hline 4 & $\begin{array}{c}\text { Alkaline phosphatase } \\
(\mathrm{IU} / \mathrm{ml})\end{array}$ & 125 & 123 & 129 & $126.6 \pm 3.0$ & 1.7 \\
\hline
\end{tabular}

Table 2. Treated group concentrations.

\begin{tabular}{|c|c|c|c|c|c|c|c|c|c|}
\hline No. & $\begin{array}{l}\text { Enzymatic } \\
\text { profile }\end{array}$ & $\begin{array}{l}\text { Days of } \\
\text { treatment }\end{array}$ & Fish 1 & Fish 2 & Fish 3 & Mean \pm S.D & $\begin{array}{c}\text { Standard } \\
\text { error of mean }\end{array}$ & $\begin{array}{l}\text { Paired T } \\
\text { test value }\end{array}$ & $\begin{array}{l}\text { Significant }(\mathrm{p}) \\
\text { value }\end{array}$ \\
\hline \multirow[t]{4}{*}{1} & \multirow{4}{*}{$\begin{array}{c}\text { LDH } \\
(\mathrm{IU} / \mathrm{ml})\end{array}$} & 1 day & 904 & 900 & 915 & $906 \pm 7.77$ & 4.48 & 150.22 & $0.0001 * * *$ \\
\hline & & 2 days & 850 & 845 & 860 & $851 \pm 7.64$ & 4.41 & 135.6 & $0.0001 * * *$ \\
\hline & & 3 days & 765 & 770 & 760 & $765 \pm 5.00$ & 2.89 & 104.6 & $0.0001 * * *$ \\
\hline & & 4 days & 504 & 590 & 543 & $545 \pm 43.0$ & 24.86 & 7.98 & $0.015^{*}$ \\
\hline \multirow[t]{4}{*}{2} & \multirow{4}{*}{$\begin{array}{c}\text { CPK } \\
(\mathrm{IU} / \mathrm{ml})\end{array}$} & 1 day & 1,787 & 1,710 & 1,715 & $1,737 \pm 43.0$ & 24.8 & 242.66 & $0.0001 * * *$ \\
\hline & & 2 days & 2,444 & 2,345 & 2,546 & $2,445 \pm 100.5$ & 58 & 93.24 & $0.0001 * * *$ \\
\hline & & 3 days & 3,600 & 3,700 & 3,855 & $3,718 \pm 128.48$ & 74.18 & 55.90 & $0.0003 * * *$ \\
\hline & & 4 days & 5,660 & 5,770 & 5,600 & $5,676 \pm 86.22$ & 49.78 & 31.60 & $0.001 * * *$ \\
\hline \multirow[t]{4}{*}{3} & \multirow{4}{*}{$\begin{array}{c}\text { SGPT } \\
(\mathrm{mmol} / \mathrm{L})\end{array}$} & 1 day & 28 & 30 & 23 & $27 \pm 3.6$ & 2.08 & 3.80 & $0.06^{\mathrm{NS}}$ \\
\hline & & 2 days & 26 & 23 & 24 & $24.3 \pm 1.52$ & 0.88 & 6.22 & $0.02 *$ \\
\hline & & 3 days & 15 & 12 & 14 & $13.67 \pm 1.53$ & 0.88 & 10.16 & $0.009 * *$ \\
\hline & & 4 days & 08 & 08 & 10 & $8.67 \pm 1.15$ & 0.67 & 11.33 & $0.007 * *$ \\
\hline \multirow[t]{4}{*}{4} & \multirow{4}{*}{$\begin{array}{c}\text { Alkaline } \\
\text { phosphates } \\
(\mathrm{IU} / \mathrm{ml})\end{array}$} & 1 day & 56 & 50 & 45 & $50.3 \pm 5.5$ & 3.18 & 16.79 & $0.003 * *$ \\
\hline & & 2 days & 26 & 30 & 34 & $30 \pm 4.0$ & 2.3 & 54.23 & $0.0003 * * *$ \\
\hline & & 3 days & 23 & 24 & 20 & $22.3 \pm 2.08$ & 1.20 & 34.78 & $0.0008 * * *$ \\
\hline & & 4 days & 16 & 20 & 17 & $17.6 \pm 2.08$ & 1.20 & 40.82 & $0.0006^{* * *}$ \\
\hline
\end{tabular}

Significant Value $=\mathrm{P}<0.05$ High Significant value $=\mathrm{P} \leq 0.01$
Maximum highly significant value $=\mathrm{P} \leq 0.001$

Non Significant Value $=\mathrm{P}>0.05$ 
group concentration is shown in Tables 1 and 2. In the present study inclined concentrations of LDH were observed throughout the experiment and maximum highly significant inclinations $(\mathrm{P} \leq 0.001)$ in concentration were observed after exposure for 24, 48, and $72 \mathrm{hrs,} \mathrm{while}$ significantly inclined $(\mathrm{P} \leq 0.05)$ concentrations of $\mathrm{LDH}$ were observed after exposure for $96 \mathrm{hrs}$, indicating that fish show the ability to produce more LDH in the body. The present study reveals that the main hepatic cellular component to be affected by the ambient toxicants seems to be the cell membrane, and such aquatic toxicants have increased membrane permeability, causing enhanced leaching out of the enzyme and as LDH participates in an anaerobic pathway, so Increase LDH mean increases of anaerobic metabolism resulting from depletion of energy under environmental stress conditions by atrazine, as shown in Fig. 1 and Table 2.

Increasing or decreasing levels of any plasma enzymes show liver damage [21-22]. LDH is an enzyme that participates in the anaerobic pathway of carbohydrate metabolism. The increase of LDH activity is a diagnostic index widely used to recognize increases of anaerobic metabolism resulting from depletion of energy under anaerobic and environmental stress conditions [23-24]. The increase of LDH activity in the whole body extract of fish was a physiological mechanism to provide more energy to deal with the effects of any stress condition [23]. The increased activity of LDH can be explained as a consequence of pathological changes in hepatic tissue [25]. Beside this in the present study inclined concentrations of LDH were observed throughout the experiment and maximum highly significant inclinations $(\mathrm{P} \leq 0.001)$ in concentration were observed after exposure for 24,48 , and $72 \mathrm{hrs}$, while significantly inclined $(\mathrm{P} \leq 0.05)$ concentrations of LDH were observed after exposure for $96 \mathrm{hrs}$, indicating that fish show the ability to produce more LDH in the body for the purpose of producing high levels of energy to cope with the stressful environment. The Present study reveals that the main hepatic cellular component to be affected by the ambient toxicants seems to be the cell membrane, and such aquatic toxicants have increased membrane permeability, causing enhanced leaching out of the enzymes. Similar changes in LDH activity were observed in crayfish exposed to endosulfan [26], and increased LDH activity in the gill and brain of tilapia, Oreochromis mossambicus, after exposure to monocrotophos was reported by Rao [27]. The present

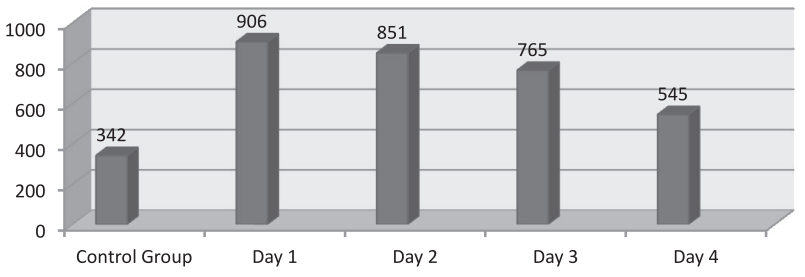

Fig. 1. Comparison of LDH mean concentrations between control and treated groups. study agrees with Yousafzai and Shakoori, who stated that the increased enzymatic activities in the liver might be due to increased enzyme synthesis to counter the damage caused by toxicants [28]. The observed increase of LDH activity can be attributed to the conversion of accumulated pyruvate into lactate, which is transported through muscle to hepatopancreas and regenerated glucose and glycogen to supply energy for fish exposed to insecticides. Similar results have been reported by Lavanya et al., Li et al., and Saravanan et al. [29-31].

The decline in CPK concentration was noticed and the highly maximum significant decline in concentration $(\mathrm{P} \leq 0.001)$ was observed throughout the whole experiment as shown in Table. 2. It was observed that CPK showed a maximum decline after exposure for $24 \mathrm{hrs}$ against the high dose of atrazine, while on reducing the quantity of dose for 48, 72, and $96 \mathrm{hrs}$, a continuous incline in concentration was observed - but still the concentration was less than the control group, which reveals that atrazine affects the concentration of CPK by decreasing it, but it also reveals that by reducing the dose the fish showed the ability to gain its normal concentration of CPK as shown in Table. 2 and Fig. 2.

A continuous decline throughout the whole experiment was observed in the concentration of SGPT against atrazine when compared with the control group concentration. A significant decline $(\mathrm{P}<0.05)$ was observed after exposure for 24 hrs while the maximum significant decline $(\mathrm{P} \leq 0.01)$ in concentration was observed after exposure for 48 and $72 \mathrm{hrs}$, while a non-significant declined in concentration was observed after exposure for $24 \mathrm{hrs}$, which reveals that the more the fish was exposed to atrazine, the more the decline in SGPT concentration and vice versa as shown in Table. 2 and Fig. 3. In another study, SGPT was investigated after exposure to sub-lethal concentrations of

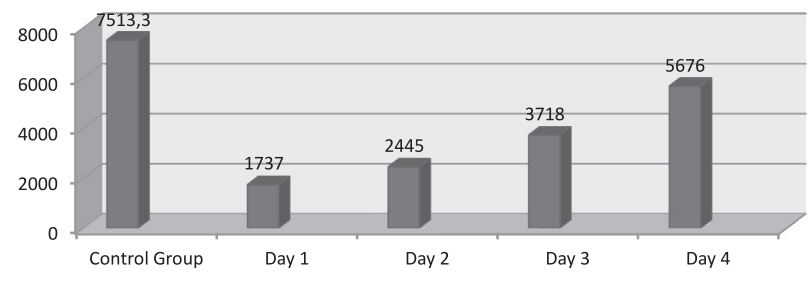

Fig. 2. Comparison of CPK mean concentrations between control and treated groups.

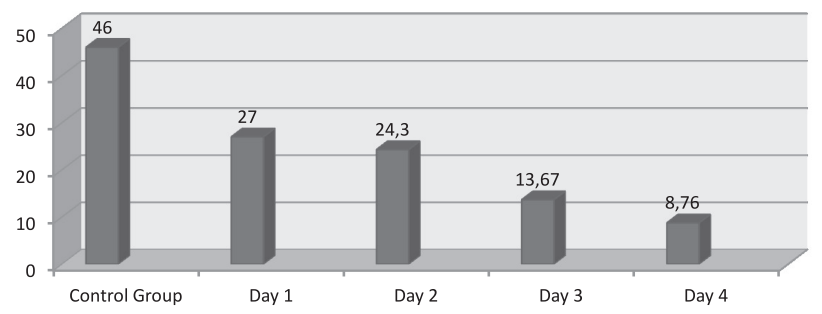

Fig. 3. Comparison of SGPT mean concentrations between control and treated groups. 
NH3-N, NO3-N, and NO2-N by the freshwater fish Catla catla (Hamilton), Labeo rohita (Hamilton), and Cirrhinus mrigala (Hamilton). Depletion in the enzyme activities was observed in all three exposed fish species, which justifies the present findings [32].

Continuous decline throughout the whole experiment was observed in the concentration of Alk Phosp against atrazine when compared with control group concentrations, and a significant decline $(\mathrm{P} \leq 0.01)$ was observed after exposure for $24 \mathrm{hrs}$, while the highly maximum declined $(\mathrm{P} \leq 0.001)$ in concentration was observed after exposure for 48,72 , and $96 \mathrm{hrs}$, which reveals that more time of exposure to a maximum decline in concentration will be noticed and vice versa as shown in Table. 2 and Fig. 4. Decreased ALP activity in Labeo rohita was observed when exposed to cypermethrin [33]. Similarly, a decline in ALP concentration was observed in rainbow trout after acute exposure to metribuzin, which justifies the present findings [34].

The declined enzymatic levels in the blood are attributable to liver damage under pathological conditions [35]. During the present study, the decline in CPK concentration was noticed and the highly maximum significant decline $(\mathrm{P} \leq 0.001)$ was observed throughout the whole experiment. A similarly continuous decline in SGPT concentration was observed throughout the whole experiment, and a significant decline $(\mathrm{P}<0.05)$ and maximum significant decline $(\mathrm{P} \leq 0.01)$ in concentration were observed after exposure for 24,48 , and $72 \mathrm{hrs}$, while a non-significant decline in concentration was observed after exposure for $24 \mathrm{hrs}$, which reveals that the more fish are exposed to atrazine, the more decline in SGPT concentration was observed and vice versa. Likewise, continuous decline throughout the whole experiment was observed in the concentration of Alk Phosp against atrazine when compared with control group concentration, and significant decline $(\mathrm{P} \leq 0.01)$ was observed after exposure for $24 \mathrm{hrs}$, while the highly maximum decline $(\mathrm{P} \leq 0.001)$ in concentration was observed after exposure for 48, 72, and $96 \mathrm{hrs,} \mathrm{which} \mathrm{reveals} \mathrm{more} \mathrm{time} \mathrm{of}$ exposure so maximum decline in concentration will be noticed and vice versa. Therefore, the decreased activities of these enzymes may be attributed to decreased enzyme synthesis, or it may also be due to changes in permeability of hepatic cells. According to [35] this could be a result of the inhibition of different enzymes due to the effect of

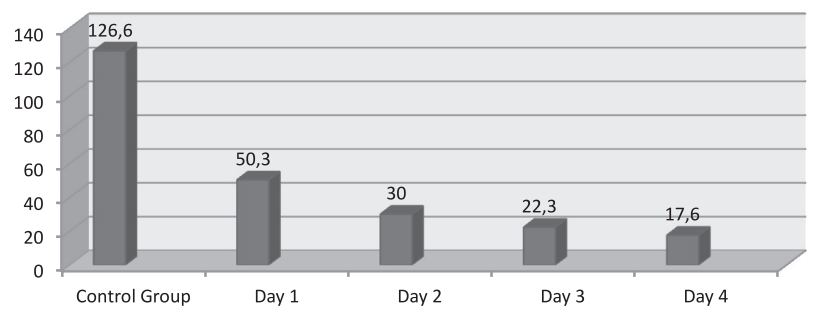

Fig. 4. Comparison of alkaline phosphatase mean concentrations between control and treated groups. the toxicant, which shows the adverse effect of aquatic pollution on fish health.

So it was concluded that atrazine was highly toxic to grass carp. Exposure to different concentrations of atrazine resulted in significant biochemical alterations, which may be potentially disruptive for the survivability of grass carp. We also concluded that measuring biochemical parameters in the present study was useful for monitoring the sublethal effects of atrazine on freshwater fish.

\section{Conclusions}

Our study proposed that the biochemical indices (enzymatic profile) of grass carp are target parameters for atrazine herbicides. The present results showed the importance and the effect of the herbicide on the natural ecosystem with an alarming rise in pollution over the years. The present study findings are used to understand the risk of atrazine herbicide to enzymatic profile of grass carp fish. In the present study, inclined concentrations of LDH and declined concentrations of CPK, SGPT, and Alk Phosp - denoted by $\mathrm{P}<0.05$ (significant), $\mathrm{P} \leq 0.01$ (highly significant) and $\mathrm{P} \leq 0.001$ (maximum highly significant) - was against different doses of atrazine, indicating an adverse effect of atrazine on grass carp as well as other aquatic fauna.

\section{References}

1. JOHN P.J. Alteration of certain blood parameters of freshwater teleost Mystus vittatus after chronic exposure to Metasystox and Sevin. Fish Physiology and Biochemistry. 33, 15, 2007.

2. VELCHEVA I., PETROVA S., MOLLOV I., GECHEVA G., GEORGIEV D. Herbicides impact on the community structure of the soil mesofauna. Bulgarian Journal of Agricultural Science. 18 (5), 742, 2012.

3. MARIN-MORALES M.A., VENTURA-CAMARGO B.D.C, HOSHINA M.M. Toxicity of Herbicides: Impact on aquatic and soil biota and human health. In: A. Price and J.A. Kelton (Eds) Herbicides - Current Research and Case Studies in Use, In Tech, Croatia, 399, 2013.

4. LUSKOVA V., SVOBODA M., KOLAROVA J. The effect of diazinon on blood plasma biochemistry in Carp (Cprinus carpio). Acta Vet. Brno.71, 117, 2002.

5. NELSON D.L., COX M.M. Lehninger, Principles of Biochemistry $3^{\text {rd }}$ Ed. Worth Publishing: New York. ISBN 1-57259-153-6. 2000.

6. WANG C.S., CHANG TING-TSUNG, YAO, WEIJEN, WANG, SHAN-TAIR, CHOU, PESUS. Impact of increasing alanine aminotransferase levels within normal range on incident diabetes. J. Formos. Med. Assoc. 111, 201, doi:10.1016/j.jfma.2011.04.004. 2012.

7. GHOURI N., PREISS D., SATTAR, NAVEED. Liver enzymes, nonalcoholic fatty liver disease, and incident cardiovascular disease: a narrative review and clinical perspective of prospective data". Hepatology. 52, 1156, 2010.

8. DONG X., ZHU L., WANG J., XIE H., HOU X., JIA W. Effects of atrazine on cytochrome P450 enzymes of 
zebrafish (Danio rerio). Chemosphere 77, 404, 2009.

9. KREUTZ L.C., BARCELLOS L.J.G., MARTENINGHE A., DOS S., ZANATTA E.D. Innate immune response of silver catfish (Rhamdia quelen) exposed to atrazine. Fish Shellfish Immunology. 33, 1055, 2012.

10. BRUN-HEATH I., TAILLANDIER A., SERRE J.L., MORNET E. Characterization of 11 novel mutations in the tissue non-specific alkaline phosphatase gene responsible for hypophosphatasia and genotype-phenotype correlations. Mol. Genet. Metab. 84, 273-73, 2005.

11. NASCIMENTO C.R.B., SOUZA M.M., MARTINEZ C.B.R. Copper and the herbicide atrazine impair the stress response of the freshwater fish, Prochilodus lineatus. Pharmacology Toxicological Endocrinology. 155, 456., 2012.

12. NWANI C.D., LAKRA W.S., NAGPURE N.S., KUMAR R., KUSHWAHA B., KUMAR S.K. Toxicity of the herbicide atrazine: effects on lipid peroxidation and activities of antioxidant enzymes in the freshwater fish, Channa punctatus (Bloch). International Journal of Environmental Research and Public Health. 7, 3298, 2010.

13. RYMUSZKA A., SIWICKI A.K., SIEROSLA W.A. Determination of modulatory potential of atrazine on selected functions of immune cells isolated from rainbow trout (Oncorhynchus mykiss). Central European Journal of Immunology. 32, 97, 2007.

14. TIERNEY K.B., SINGH C.R., ROSS P.S., KENNEDY C.J. Relating olfactory neurotoxicity to altered olfactorymediated behaviors in rainbow trout exposed to three currently-used pesticides. Aquatic Toxicology. 81, 55, 2007.

15. FATIMA M., MANDIKI S.N.M., DOUXFILS J., SILVESTRE F., COPPE P., KESTEMONT P. Combined effects of herbicides on biomarkers reflecting immuneendocrine interactions in goldfish immune and antioxidant effects. Aquatic Toxicology. 81, 159, 2007.

16. LIONETTO M.G., CARICATO R., GIORDANO M.E., ERROI E., SCHETTINO T. Carbonic anhydrase as pollution biomarker: an ancient enzyme with a new use. International Journal of Environmental Research and Public Health. 9, 3965, 2012.

17. TILLITT D.E., PAPOULIAS D.M., WHYTE J.J., RICHTER C.A. Atrazine reduces reproduction in fathead minnow (Pimephales promelas). Aquatic Toxicology. 99, 149, 2010.

18. NELSON D.L., COX M.M. Lehninger Principles of Biochemistry. 4th ed.; WH Freeman and Co. New York. 1013, 2004.

19. GUYTON A.C., HALL, JOHN E. Guyton and Hall Textbook of Medical Physiology with Student Consult Online Access $\left(11^{\text {th }}\right.$ ed.). Philadelphia: Elsevier Saunders. ISBN 0-7216-0240-1, 2006.

20. ZIKIC R.V., STAJN S., PAVLOVIC Z., OGNJANOVIC B.I., SAICIC Z.S. Activities of superoxide dismutase and catalase in erytrocyte and plasma transaminases of goldfish (Carassius auratus gibelio Bloch.) exposed to cadmium. Physiological Research. 50, 105. 2001.

21. DATTA S., SAHA D.R., GOSH D., MAJUMDAR T., BHATTACHARYA S., MAZUMDER S. Sub-lethal concentration of arsenic interferes with the proliferation of hepatocytes and induces in vivo apoptosis in Clarias batrachus L. Comparative Biochemistry and Physiology. 145, 339, 2007.

22. ROY S., BHATTACHARYA S. Arsenic-induced histopathology and synthesis of stress proteins in liver of
Channa punctatus. Ecotoxicological and Environmental Safety. 65, 218, 2006.

23. BANAEE M., SUREDAA., MIRVAGHEFI A.R., AHMADI K. Effects of Diazinon on Biochemical Parameters of Blood in Rainbow Trout (Oncorhynchus mykiss). Pesticide Biochemistry and Physiology. 99, 1, 2012.

24. BANAEE M., SUREDA A., MIRVAGHEFI A.R., AHMADI $\mathrm{K}$. Biochemical and histological changes in the liver tissue of Rainbow trout (Oncorhynchus mykiss) exposed to sublethal concentrations of diazinon. Fish Physiology and Biochemistry. 39, 489, 2013.

25. DOUBEK J., SLOSARKOVA S., REHAKOVA K., BOUDA J., SCHEER P., PIPERISOVA I., TOMENENDALOVA J., MATALOVA E. The interpretation of basic biochemical and hematological indices in animals. Noviko Czech Republic, 102, 2010 [In Czech].

26. BANAEE M., AHMADI K. Sub-lethal Toxicity Impacts of Endosulfan on some biochemical Parameters of the Freshwater Crayfish (Astacus leptodactylus). Research Journal of Environmental Sciences. 5 (11), 827, 2011.

27. RAO J.V. Biochemical alterations in euryhaline fish, Oreochromis mossambicus, exposed to sub-lethal concentrations of an organophosphorus insecticide, monocrotophos. Chemosphere. 65, 1814, 2006.

28. YOUSAFZAI A.M., A.R SHAKOORI. Hepatic responses of a freshwater fi sh against aquatic pollution. Pakistan Journal of Zoology. 43 (2), 209, 2011.

29. LAVANYA S., RAMESH M., KAVITHA C., MALARVIZHI A. Hematological, biochemical and ionoregulatory responses of Indian major carp, Catla catla during chronic sublethal exposure to inorganic arsenic. Chemosphere. 82 (7), 977, 2011.

30. LI Z H., VELISEK J., GRABIC R., LI P., KOLAROVA J., RANDAK T. Use of hematological and plasma biochemical parameters to assess the chronic effects of a fungicide propiconazole on a freshwater teleost. Chemosphere, 83 (4), 572, 2011.

31. SARAVANAN M., KARTHIKA S., MALARVIZHI A.M., RAMESH. Ecotoxicological impacts of clofi bric acid and diclofenac in common carp (Cyprinus carpio) fingerlings: hematological, biochemical, ionoregulatory and enzymological responses. Journal of Hazardous Materials. 195, 188, 2011.

32. TILAK K.S., VEERAIAH K., LAKSHMI S.J. Studies of some biochemical changes in the tissues of Catla catla (Hamilton), Labeo rohita (Hamilton) and Cirrhinus mrigala (Hamilton) exposed to NH3-N, NO2- N and NO3-N. Journal of environmental biology 23, 377, 2002.

33. DAS B.K., MUKHERJEE S.C. Toxicity of cypermethrin in Labeo rohita fingerlings: biochemical, enzymatic and haematological consequences. Comparative Biochemistry and Physiology. Toxicology and Pharmacology. 134, 109, 2003.

34. VELISEK J.Z., SVOBODOVA V., PIACKOVA L., NOVOTNY J., BLAHOVA E., SUDOVA, MALY V. Effects of metribuzin on rainbow trout Oncorhynchus mykiss. Veterinarni Medicina. 53, 324. 2008.

35. BANAEE M., MIRVAGEFEI A.R., RAFEI G.R., MAJAZI A.B. Effect of sub-lethal Diazinon Concentrations on Blood Plasma Biochemistry. International Journal of Environmental Research. 2, 189, 2008. 